\title{
University capability as a micro-foundation for the Triple Helix model: the case of China
}

Article

Accepted Version

Creative Commons: Attribution-Noncommercial-No Derivative Works 4.0

Liu, Y. and Huang, Q. (2018) University capability as a microfoundation for the Triple Helix model: the case of China. Technovation, 76-77. pp. 40-50. ISSN 0166-4972 doi: https://doi.org/10.1016/j.technovation.2018.02.013 Available at https://centaur.reading.ac.uk/81587/

It is advisable to refer to the publisher's version if you intend to cite from the work. See Guidance on citing.

To link to this article DOI: http://dx.doi.org/10.1016/j.technovation.2018.02.013

Publisher: Elsevier

All outputs in CentAUR are protected by Intellectual Property Rights law, including copyright law. Copyright and IPR is retained by the creators or other copyright holders. Terms and conditions for use of this material are defined in the End User Agreement.

www.reading.ac.uk/centaur

\section{CentAUR}


Central Archive at the University of Reading

Reading's research outputs online 


\title{
University capability as micro-foundation for Triple Helix model: The case from China
}

\begin{abstract}
This paper aims to advance our understanding of the Triple Helix model from a microfoundational perspective by articulating the notion of university capability. From an external evaluative viewpoint we suggest that university capability consists of (1) resource base, (2) motivation/objective, (3) resource allocation and coordination mechanisms, and (4) regional outcomes. Based on qualitative data collected from two leading cities in innovation and regional development in China, our study unpacks university capability by distinguishing resources and capabilities. Furthermore, this paper empirically elucidates two different approaches to deal with university capability. Our conceptualization of university capability may be a useful analytical tool to better understand the role of 'university' and its relationship with the other actors in the Triple Helix model.
\end{abstract}

Key words: Triple Helix, micro-foundation, university capability, regional development, innovation, entrepreneurial university, returnee entrepreneur 


\section{Introduction}

Accordingly to the Triple Helix model, the easy movement across organizational boundaries among three components, university-industry-government, can smooth the knowledge flow and engender regional innovation and regional development, where university plays a leading role (Etzkowitz, 2008, 2012). This is supported by empirical research, largely based on observations of such development and data collected in a few most developed countries (Anderson, Daim, \& Lavoie, 2007; Balconi \& Laboranti, 2006; Etzkowitz, Webster, Gebhardt, \& Terra, 2000; Jacob, Lundqvist, \& Hellsmark, 2003; Lawton Smith \& BagchiSen, 2010). Consequently, policies in Europe appear to have converged on a number of initiatives aimed at transforming universities into central components of the knowledge infrastructure for innovation (Jacob et al., 2003).

However, available research has three deficiencies. First, it does not have a clear explanation of what university capability is. Second, it appears to have ignored the fact that universities in transitional and developing countries do not readily have such 'implicitly' assumed capability as in the context of developed economies (Wright, Liu, Buck, \& Filatotchev, 2008). Third, it tends to take a static perspective, and neglects the dynamic interaction among the three actors and therefore process, through which regions which may not possess readily available capability can have the potential to address such capability in fostering regional development and innovation.

This paper therefore aims to fill an important knowledge gap, namely, what is university capability. Our contribution is two-fold. First, it is among an early effort to conceptualize university capability by examining its key elements in terms of interaction with the other actors in the Triple Helix model. This paper differentiates university resource and university capability by drawing on the research stream on organizational capability (Amit \& Schoemaker, 1993; Grant, 1996; Teece, Pisano, \& Shuen, 1997). Second, the Triple Helix literature tends to pay comparatively little attention to micro-level constructs (Felin, Foss, \& Ployhart, 2015). A few recent studies from a micro-foundational perspective mainly focus on individual-level phenomenon such as technology transfer office or PIs (Mangematin, O'Reilly, \& Cunningham, 2014; O'Kane, Mangematin, Geoghegan, \& Fitzgerald, 2015) without much attention geared towards organizational-level constructs, such as university capability. By unpacking this micro-level construct and incorporating the micro-foundational thinking (Barney \& Felin, 2013; Devinney, 2013), our study attempts to delineate two different approaches how university capability can be addressed and contributes to regional development. By using both primary and secondary data collected from two leading cities in innovation and regional development in an emerging economy, China, our research reveals how external audience evaluates different key components of university capability. Furthermore, it identifies two different approaches for regions to fulfill the key functions of university for regional development.

In the next section, we review the role of university in the Triple Helix model and prevalent assumptions, which will be used to help articulate and unpack university capability by distinguishing resources and capabilities. Then, we explain research method including 
research context, data collection and data analysis. In the finding section, we report audience evaluative views from the other two actors in the Triple Helix model on university capability respectively. We further elucidate two different approaches in addressing university capability. The last two sections of the article offer discussion, theoretical and policy implications, and conclusion.

\section{Literature review}

\subsection{University in the Triple Helix model}

According to Triple Helix model (Etzkowitz et al., 2000; Leydesdorff \& Etzkowitz, 1998), the interaction of university-industry-government facilitates the flow of knowledge and contributes to regional innovation and development, as illustrated in cases such as MIT and Boston, and Stanford and Silicon Valley in the USA (Etzkowitz, 2012), and Oxfordshire in the UK (Lawton Smith \& Bagchi-Sen, 2010), where universities play the role as the primary institutions (Etzkowitz, 2008). Existing research, including the term of entrepreneurial university (Etzkowitz, 2003), has documented the contribution universities can make to regional development (Lawton Smith \& Bagchi-Sen, 2012; Marques, Caraça, \& Diz, 2006; O'Kane et al., 2015). However, there is an important knowledge gap in the existing literature, explicitly, no shared understanding of the notion of university capability. Much research tends to equal university capability to university activities or functions in relevance to regional development. For example, university capability is seen as a flow or activity (Lockett \& Wright, 2005; Youtie \& Shapira, 2008). However, rooted in the organizational and management studies, capability refers to "the ability of an organization to perform a coordinated set of tasks, utilizing organizational resources, for the purpose of achieving a particular end result" (Helfat \& Peteraf, 2003: 999). Hereby, resources and capabilities need to be treated separately.

University can be an important source of learning and innovative know-how, which is critical to the region development, with provision of students, academic and research staff (Anderson et al., 2007; Carayannis, Alexander, \& Ioannidis, 2000). However, there may be no knowledge transfer between the university and local firms if neither side has interest, motivation or mechanisms in place. Lockett \& Wright (2005) therefore suggest the importance of process for spinning-out companies. Not surprisingly, researchers argue for the importance of boundary spanners, who can bridge different areas, academia, higher education, policy makers and firms (Mangematin et al., 2014). However, universities may still fail in delivery of what they intended to achieve in knowledge exchange. For example, a lack of recognition from university management can result in technology transfer offices (TTOs) being under-resourced in their role, which in turn can deter their efforts and perform (O'Kane et al 2015). Even with certain resource available, university may not succeed in desired outcomes. There are examples where universities have endeavored to foster knowledge transfer, but have not had a great impact on their regional economies (Youtie \& Shapira, 2008). Therefore, there is the urgent need to illuminate the relationship between university 
capability, various activities and resource (Lockett \& Wright, 2005). An important step is to define what university capability is, before we apply it as an analytical framework.

\subsection{Unpacking university capability by distinguishing resources and capabilities}

Some available research appears to have examined university capability (Lockett \& Wright, 2005; Rasmussen \& Borch, 2010). However, the researchers tend to focus on narrow aspects of university capability, for example, Business Development Capability (Lockett \& Wright, 2005), or similarly, the venture-formation process (Rasmussen \& Borch, 2010), which is about the extent to which the university has the ability to generate spin-outs. University capabilities are simply seen in this particular context as 'routines to promote entrepreneurial processes within the university and refer to the ability of the university organization to facilitate the spin-off-formation process' (Rasmussen \& Borch, 2010:604). It thus lacks of clarity of the construct 'university capability' in the context of Triple Helix model. Nevertheless, such research provides a helpful direction for a more comprehensive understanding of university capability, a gap, which the current paper aims to fill.

Amit \& Schoemaker (1993) define capability as a firm's capacity to purposefully deploy a combination of resources and processes to achieve a desired goal. Grant (1996:377) understands organizational capability 'as a firm's ability to perform repeatedly a productive task which relates either directly or indirectly to a firm's capacity for creating value through effecting the transformation of inputs into outputs'. Resource or input apparently is a critical element of capability. However, it is clear that capability is more than resource. A resource can be defined as a tangible or intangible asset or input to production that an organization owns, controls, or has access to on a semi-permanent basis (Helfat \& Peteraf, 2003).

By contrast, a capability can be harnessed against the opposition of circumstance to produce desirable outcomes (Teece, 2014). In the example of spin-offs, the key resource inputs for university spin-offs include technology stock, technology transfer office/staff, and experience of spinning-out companies (Lockett \& Wright, 2005), whereas capabilities are defined as routines, involving processes for assessing intellectual property rights, processes for spinning-out companies, and skills embodied in university staff in terms of both managing the commercialization process and specific technical and marketing skills. Similarly, the three university capabilities identified by Rasmussen and Borch (2010) characterize how university allocate and coordinate resources for university spin-off companies during the venture-formation process. However, their research focuses largely on internal process but neglects the process and mechanism of interaction with the external actors in the context of Triple Helix. The university capability in coordinating and allocating resources, interacting with and responding to the external environment and opportunity, appears even more important.

Therefore, we suggest that university capabilities in the Triple Helix model should include four key elements: (1) resource needed or beneficial to regional development, e.g. human capital and know-how or knowledge hub (Lockett \& Wright, 2005; Youtie \& Shapira, 2008); (2) the motivation or objectives to work with the other two actors, e.g. missions of 
entrepreneurial university (Fugazzotto, 2009); (3) mechanisms to coordinate and allocate resource to achieve the objectives, e.g., knowledge transfer (Lockett \& Wright, 2005; Rasmussen \& Borch, 2010); and (4) the desired regional outcomes, e.g. its contribution to regional development by knowledge transfer and innovation (Anderson et al., 2007;

Leydesdorff \& Etzkowitz, 1998; Mangematin et al., 2014; Youtie \& Shapira, 2008). In turn, how external stakeholders evaluate university capability not only reflects their perception of the possibility for collaboration but also a university's internal capability. For instance, a firm will be encouraged to seek collaboration with a university which demonstrates commitment in engagement with industry.

\subsection{Assumptions and approaches on university capability}

In addition to the above mentioned ambiguity of the construct, available research seems to share two basic assumptions about university capability in the Triple Helix model. One assumption is that the three actors, namely university, firm, and government, are located in the proximate geographic location, which neglects that fact that knowledge can flow beyond geographic boundaries (Bathelt, Malmberg, \& Maskell, 2004). Furthermore, in the age of globalization and global talent mobility (Wang \& Liu, 2015), knowledge may roam the globe almost frictionless. Such knowledge flow and particular mobility of knowledge workers could be an alternative to local availability of university capability, as shown in the emerging literature on global talent movement (Stokes et al., 2015) and entrepreneurial mobility (Liu \& Almor, 2014).

Another assumption denotes that the universities in the Triple Helix model always seem to possess readily 'university capability'. However, this assumption ignores the phenomenon that regions which did not have readily university capability have been successful in innovation and regional development especially in the context of emerging economies (Liu, Cao, \& Xing, 2013). Universities in emerging economies might possess relatively lower capability in generating and transferring innovative technology (Wright et al., 2008). Therefore, one option for regions with relatively low university capability is to develop such capability. Thus, regional conditions and circumstances have an important bearing on university capability on the one hand, whereas university can contribute to local regional development on the other hand. We, therefore, specified regional outcomes in the fourth element of university capability.

In light of our conceptualization of university capability, we connect activities and functions to university capability by building upon U-Map (Bartelse \& van Vught, 2009). U-Map, as the European Union's project to assess research activities of European university, includes six dimensions of activities/profile of a university covering university functions indicated by the available literature: 1) teaching and learning in terms of number of degrees in different subjects awarded at different levels, 2) diversity and size of students, 3) research involvement, 4) regional engagement, 5) involvement in knowledge exchange, and 6) international orientation. The sixth dimension can be part of regional development, e.g., international students as a bridge between the region and their home countries. Therefore, we suggest the activities and functions can be categorized into knowledge base, knowledge exchange and 
outcomes of regional development, e.g. regional milieu. In so doing, we also consider the regional dimension of university capability by investigating the outcomes of regional development (Lawton Smith \& Bagchi-Sen, 2010, 2012). By considering both activities and contribution of these activities to regional development through the three categories, we aim to obtain a nuanced understanding of university capacity in the Triple Helix model.

\section{Research methodology}

\subsection{Research context}

We chose two second tier but leading cities in innovation and regional development in China, Suzhou and Wuxi respectively, two neighboring cities in Jiangsu Province, close to Shanghai, as the empirical setting to investigate our research questions. The timeframe for our observation ranges from 2000 to 2013, mainly due to three reasons: 1) both cities began to explore possible pathways in the strategic shift to a high-tech/knowledge-based economy from a manufacturing-based economy, 2) both city governments realized the importance of the high-tech sector and knowledge-based economy and initiated policy intervention, 3) the duration of our observation of these two cities holds constant defined by the temporal contextual dimension (Zahra, Wright, \& Abdelgawad, 2014). In so doing, our study tried to form a comparable background in terms of the focus on building a knowledge-based economy by illuminating the role of university and university capability in the Triple Helix model.

The two cities compete against each other while sharing commonalities and differences with regard to regional economic development. Wuxi, with the nickname of "little Shanghai" accumulated a well-developed industrial foundation before 1949 when P.R. China was established. During 1970s, both Suzhou and Wuxi experienced similar economic development pattern although Suzhou possessed relatively larger administrative territory than Wuxi. During the1980s, Wuxi enjoyed quicker economic development than Suzhou, thanks to its strength in township and village enterprises. The once famous "SuNan Model" reflected the successful experiences of Wuxi (Wei, Lu, \& Chen, 2009). 1990s saw Suzhou on a fast track by developing the Economic Development Zone (EDZ) and implementing a FDI (Foreign Direct Investment)-oriented regional policy. In particular the establishment of China-Singapore Suzhou Industrial Park (SIP) in 1994 by the Chinese and Singaporean governments with involvement of their agencies and various private sector organizations aimed at establishing a world-class industrial park to transfer advanced technologies, industrial projects as well as management experience from Singapore to China (Yeoh, Pow Ngee How, \& Lin Leong, 2005). Even though Wuxi also endeavored to attract FDI by establishing Wuxi New District, it was lagged behind by Suzhou.

Since 2000, both regions began the strategic shift to a knowledge-based economy from the manufacturing-centric economy. The manifestation with Suzhou was the establishment of a series of universities or research institutions from both domestic institutions (e.g. University of Science and Technology of China Suzhou Institute for advanced study was established in 
2003) and foreign ones (e.g. Xi' an Jiaotong-Liverpool university in 2006) in response to the local firms' need, particularly foreign invested firms in the Suzhou Industrial Park. In contrast, Wuxi developed its own pathway by attracting overseas talent to boost its innovation and local economy, such as the founding of Suntech power, the first Chinese solar energy company that went public in NYSE by December 2005 (Liu, 2011). Consequently, Wuxi initiated the government-driven policy to attract overseas talent to found technology ventures in Wuxi. The divergent regional development trajectory grants the opportunity to observe regional development and innovation from a comparative lens bearing with the same overarching theme in building and developing a knowledge-based economy.

\subsection{Qualitative research method}

We adopted qualitative research methods in investigating our research questions. The nature of our research questions suggests the appropriateness of using qualitative methods. In order to obtain a nuanced understanding, scholars emphasized the advantages of using a methodological pluralism approach in examining entrepreneurial activities (Coviello \& Jones, 2004; Leitch, Hill, \& Neergaard, 2010). We sought to reveal the underlying mechanisms, and social dynamics by using several complementary sources of data, and methods of analysis (Vaara \& Monin, 2010). Therefore, we utilized a multi-method approach consisting of case studies (Eisenhardt \& Graebner, 2007) and content analysis (Krippendorff, 2012). In-depth interviews with key actors can provide insights into the mechanisms of regional innovation and development, whose richness is beyond what could have been extracted from the documentary data. In addition, we applied content analysis to examine the regulatory and policy documents to triangulate with the primary interview data (Yin, 2009). The combination of primary and secondary data facilitated our research endeavor to enhance the trustworthy of our data analysis. It also engendered a fine-grained and nuanced understanding of university capacity and the interactive process of relevant stakeholders captured by the Triple Helix model.

\section{3. $\quad$ Sample and data collection}

We collected our primary and secondary data as part of a broader research project on Chinese technology entrepreneurship and regional innovation. We opted to focus on assembling various aspects of audience with respect to the role of university and its capability in regional development and innovation. As for primary data, in total, we conducted 29 in-depth interviews with governmental officials, university managers and faculty staff, high-tech entrepreneurs and local business people in Wuxi and Suzhou. Throughout the data collection, the authors sought to discuss the interviews and observations that formed the basis of our data. This sharing process allowed us to adjust our inquiry directions and hone interview techniques continuously. We ended the primary data collection when additional interviews did not engender significant new insights with respect to our research questions (Yin, 2009). Some examples of the key questions are, 'What is your view on the role of university to the 
regional development?', 'How do you evaluate the existing university activities for regional development?' and 'Have you ever worked with a university, if yes, on what capacity?' Table 1 displays informants included in this study in a role-ordered matrix (Miles \& Huberman, 1994).

$* * * * * * *$

Insert Table 1 about here

$* * * * * * *$

Fine-grained case studies can provide insightful information (Eisenhardt, 1989; Eisenhardt \& Graebner, 2007; Yin, 2009). The secondary data is drawn from archives, which are openly disclosed key policy documents in government agencies and departments in Suzhou and Wuxi (see Table 2).

$* * * * * * *$

Insert Table 2 about here

$* * * * * * *$

Taken together, this multi-faceted data collection approach allowed for the generation of a detailed and in-depth account of what university capability is from an audience evaluative perspective.

\section{Findings}

In this section, we report our findings to answer the key research question, i.e., what is university capability by mapping out the four elements of university capability with the three dimensions of university function. Following the U-map project in the context of evaluating European universities (Bartelse \& van Vught, 2009), we aim to illustrate the underlying mechanisms, which connect resources and capabilities to achieve different functions.

\subsection{Audience evaluative perspectives on university capability}

An university must bear certain capability in order to play such a strategic role in the Triple Helix model, in the knowledge-based economy (Etzkowitz, 2008). Based on the four key elements of university capability we conceptualized, in Section 2.2, we compare two universities, Jiangnan University (JU) in Wuxi and Xi'an Jiaotong Liverpool University 
(XJLU) in Suzhou to represent two different circumstances in the two regions respectively, as shown in Table 3.

$* * * * * * *$

Insert Table 3 about here

$* * * * * * *$

Firstly, the two universities appeared to have divergent positioning as reflected in their mission statements and objectives. Mission statement can resonate with the motivation (Morphew \& Hartley, 2006), strategy and positioning of the university (Fugazzotto, 2009). In the discourse of entrepreneurial university, mission statement constitutes as a robust proxy to reflect the interest, motivation and objectives of the university (Foss \& Gibson, 2015). JU was a specialized university in light industry and endeavored to become a comprehensive university by merger of three local colleges in 2001. By contrast, XJLU is the first SinoBritish university between Xi' an Jiaotong University and Liverpool University, both research led universities, exploring new educational models for China. From its inception, XJLU bears with an international profile at outset with research power. It states clearly its third mission as 'integrating into global economic and social development with its expertise in business and technology'. Furthermore, XJLU carries a strong commitment to use knowledge to promote regional economic development. By contrast, JU claims to 'Demonstrate our distinguished features in light industry to serve the people' and 'Innovate our cultivating pattern to form backbone of the industry'. Although both universities have mission statements, XJLU appears to emphasize the global outlook and international reach, whereas JU has a relatively narrower focus for a particular industry. The variation of mission statement resonates with the different positioning of each university, which in turn affects the motivation and willingness to collaborate in regional development.

Secondly, there exists a gap between the two universities in terms of resource endowment for potential contribution to innovation and regional development. Besides Xi' an Jiaotong University's 985 status (the Chinese government initiative to support 38 most promising universities), Liverpool University is a member of the Russell Group that represents 24 leading UK research universities, XJLU is therefore able to mobilize the resources and leverage intellectual capital from resource-rich parent universities.

Our data analysis shows that local governments mainly view university as education provider such as teaching and training and also the (potential) knowledge base for commercialization of university research. Such expectations are also manifested in particular the Suzhou institutes of the universities which have their presence in Suzhou as 'a platform for collaboration with industry in the region'. Dushu Lake Higher Education Town (HET) was established in Suzhou in 2002, with the purpose of nurturing regional innovation through the establishment of higher education institutions and research institutes while building linkages between research and local industries. 
Hence, universities must possess the capability to offer qualified teaching portfolios and learning opportunities to students. Tim, head of local department of education and technology explained,

"I think universities should offer quality educational opportunities to students. It is very important that they have high caliber faculty and teaching programs beyond just the modern buildings. Teaching and learning should be one of the key missions of modern universities.

The view from government toward university capability largely conforms to the key dimension of knowledge base. Essentially, from a public policy perspective, university is supposed to be able to contribute to regional development by offering solid education, research and scientific knowledge base as well as the potential to engage with local government. For instance, providing policy consultancy with respect to regional development was highlighted by local government officials, which is apparently expected one aspect of university expertise and knowledge exchange. James, science and technology policy department shared his view,

"We have some policy-related funding schemes that are open to universities. We hope that universities can offer valuable suggestions and recommendations for our regional development. For instance, we want to build a sustainable region and would like to hear how universities can contribute to this agenda."

Furthermore, the vast foreign invested firms in Suzhou provide XJLU with many opportunities to collaborate on industry projects. By contrast, historically as a specialized university, JU has the strength in light industry such as food and clothing production. However, it lacks expertise in the emerging high-tech industry, which the local government intended to develop, e.g. new energy technology, resulting in limited scope for collaboration with industry.

Thirdly, the above two aspects lay out the background for further differences in co-ordination mechanisms and desired outcomes. XJLU appeared able to engage with industry and satisfy industry demands through knowledge transfer and commercialization of university projects. Besides labor supply, collaboration between firms and universities more closely to undertake $R \& D$ projects emerged as another key point, which represents a key expectation of university capability, namely knowledge exchange. Sue, R\&D manager of a multinational company explained,

"As we are in the high-tech sector, we try to corporate with local research institutions and universities to carry out some research projects. We are more interested in the application side of the scientific research. So far, we have worked with three research institutes located here on four projects."

Universities possess the knowledge base for commercialization activities. The academic entrepreneurship was tried out in Suzhou by faculty members of some university. Furthermore, the collaborative activities between university and industry denote one 
important vehicle to transfer and translate the knowledge base to practice. Mark, a university professor from the Suzhou subsidiary of a foreign university echoed this,

"As a leading research institute, we can offer what firms seek for regarding potential collaborative $R \& D$ projects. I think Suzhou government's support to establish Dushu Lake Science and Education Innovation District is of strategically importance for the region's development and innovation."

As indicated above, this reflects the co-ordination mechanisms of university capability through research collaboration with industry partners. In a similar vein, industry in Wuxi also expects knowledge exchange and collaboration with university. Jason, owner of a privatelyowned solar energy firm, emphasized,

"As a high-tech firm, we urgently need talent and expect the local university to supply. However, the university here is relatively weak for supplying talent and potential collaborative work. Fortunately, we have returnees in Wuxi that we could recruit as talent, or collaborate with to transfer knowledge."

However, our field work also found frustration experienced by industry aiming to work with university. For instance, one business person complained that he was not able to find whom to talk with within a university. Therefore, the co-ordination mechanisms between XJLU and JU vary significantly, albeit the diverging mechanisms constitute the third key element of university capability.

To summarize, the view from industry and government largely conforms to knowledge base and knowledge exchange. The focus point has been on the labor workforce provision of university graduates and how to enhance potential collaboration between university and industry for the purpose of knowledge exchange.

Fourthly, the desired outcomes in terms of their contribution to regional development vary accordingly. XJLU was the outcome of responses to foreign invested firms and regional development in Suzhou. The economic development necessitates the establishment of a comprehensive university with coverage of Science, Technology, Engineering, Architecture and Business disciplines. Moreover, it is part of planned projects within the Suzhou Dushu Lake Higher Education Town (HET) by the local government. By contrast, JU was formed amid the consolidation and merger of universities in China to enhance the operational efficiency. Constrained by its disciplines, it failed to contribute more to local development in the high- tech sector. Local government turned to returnee entrepreneurial talent, to compensate the capability needed for innovation and regional development in high-tech sector.

For instance, Tim, a manager of China-Singapore Suzhou Industrial Park (SIP), a local government official, shared his thoughts:

"Good students want to read top universities, but most of the top-tier Chinese universities are cluttered in big cities, like Shanghai and Beijing. We are lucky to have now campuses operated by top universities both from China and foreign 
countries attracting students. Furthermore, we now can see more and more university graduates who want to stay on and work here, contributing to the local economy. "'

Local government recognized the importance of university capability and its contribution to regional innovation and development.

Similarly, industry largely expected that university should serve as source of high quality labor and facilitate close university-industry collaboration, which highlights the role of university as knowledge base and its function to transfer knowledge for regional development. The presence of universities appeared to have enhanced the regional development milieu. One entrepreneur whose business was located in HET we interviewed shared with us his thought why he was not willing to relocate,

"Another high-tech park approached and tried to persuade me to relocate my business there by offering attractive tax reduction and free office space. But I get used to working in this kind of university environment where you can easily access to the universities. Also you can easily attract new graduates."

To summarize, our data analysis shows that university capability encompasses four key elements, whereas resource only addresses one element. Nevertheless, the possession of resources enables the potential articulation and manifestations of capabilities. Furthermore, the motivation/objective and co-ordination mechanisms enable the process of transferring resources into capabilities, so as to achieve desired regional outcome. From an audience's perspective, university is expected to supply highly qualified labor, transfer knowledge, and to cultivate a supportive atmosphere in embracing entrepreneurship and innovation in the region.

\section{2. $\quad$ Approaches in addressing university capability}

Our fieldwork empirically shows two possible pathways in addressing university capability. One is nurturing university capability. The other is substituting university capability by using alternative organizing form, a herd of returnee entrepreneurs. Hereby, we juxtapose the two possible approaches and illuminate the mechanisms through which university capability is addressed along the three dimensions, i.e., knowledge base, knowledge exchange and regional outcomes, as summarized in Table 4.

\subsubsection{Nurturing university capability}

One rather clearly direct approach is building up and nurturing university capability as evidenced in Suzhou. Amid the rapid regional economic growth by attracting FDI and MNCs in the manufacturing sector, Suzhou realized the important role talent may play in the developmental trajectory from a manufacturing-centric economy to a knowledge-based economy (Liu et al., 2013). In the context of establishing the Suzhou Dushu Lake Higher Education Town (HET) within SIP in 2002, with the purpose to nurture regional innovation through introducing and establishing higher education institutions and research institutes, at 
the outset, the HET aimed to attract domestic top-tier universities to establish research institutions, as knowledge brokerage for potential commercialization of universities' scientific and technological research outcomes and patents. It was followed by the entry of a series of foreign higher educational institutions in Suzhou.

Mike, HET manager, explained the development of attracting universities and research institutions,

"We began with University of Science and Technology of China (USTC), one of the best science and technology universities in this country. In 2003 USTC Suzhou Institute for advanced study was initiated as a graduate school. Beyond domestic universities, we also attracted foreign higher institutions. For instance, the first Sinoforeign joint university in China, Xi'an Jiao Tong-Liverpool University, was established and located in the central area of HET in 2006."

Suzhou government proactively attracted universities by hosting promotion events domestically and internationally to introduce government policy, such as free land. In particular, a designated area was selected to locate universities for better resource sharing and closer industry-university collaboration. Since its inception, Dushu Lake HET has attracted 25 higher education institutions, with a total of over 76,000 students registered, and over 5,000 faculty staff. It established a rotation station for Fellows of the Chinese Academy and 38 post-doc rotation stations, 5 national-level incubators, and 4 province-level incubators, with the plan to build 201 R\&D platform.

The establishment of new universities and institutions in Suzhou provides the knowledge base for teaching and learning by recruiting international faculty and students. Furthermore, faculty members from newly established higher education institutions can explore the dual career option as academic entrepreneurs to found science and technology ventures. The industry landscape in SIP offers them the potential market for such academic entrepreneurial endeavors.

Furthermore, knowledge exchange between university and industry was enabled through collaborations and joint research projects. Also, students might become the knowledge carrier by undertaking internships with industry partner. In so doing, the mission of bridging research and local industries was experimented.

Tom, a member of staff from a newly established university articulated the role of university in this interaction process in Suzhou,

"Newly established universities can act as the hub to connect different partners from industry and business sectors. Local government support plays a very important role to enable this university-industry collaboration, such as funding the programs that involve both university and industry."

The establishment of universities and research institutes in Suzhou over time appears to have built certain aspects of university function, and largely compensated the lack of university 
capability. For instance, the basic function of teaching and learning has been realized in a relatively short space of time, since universities are able to attract both students and staff.

One government official in Suzhou said,

"It would not have been possible for Suzhou to have expertise or students trained in the needed disciplines, as you know creating a new subject and degree scheme need approval from the ministry of education. Fortunately the institutes set up by the leading universities help us solve this problem."

However, it remains challenging in addressing university capability by building new university. For example, the director of Suzhou Institute of WH University admitted the same challenge shared by his counterparts,

"We aim to assist scientists in our parent university who want to locate their commercialized businesses in Suzhou. However, due to distance (six hours by high speed train from the parent university to Suzhou), it is not happening. Also, we helped the parent university win joint research bids from Suzhou but research has to be conducted back in the home location due to constraint of facility."

This indicates more complex issues and potential challenges, which might occur when nurturing university capability is adopted as the approach in addressing university capability.

$* * * * * * *$

Insert Table 4 about here

$* * * * * * *$

\subsubsection{Collective entrepreneurial activities to substitute university capability}

Another approach in addressing university capability is in the form collective entrepreneurial activities by returnee entrepreneurs and their association. As our empirical evidence from Wuxi indicates below, this approach can alternatively achieve the key functions of university, so as to address 'university capability'. It thus substitutes, to a certain extent, the absence of universities in regional innovation and development.

Wuxi attracted overseas talent to found new technology ventures in the region by launching the policy initiative "530 Plan" in 2006. The origin of the "530 Plan" in Wuxi dated back to a contingent opportunity searching behavior by returnee entrepreneurs. Dr. Shi received financial and infrastructural support from Wuxi government and founded Suntech Power in Wuxi in 2001. The success of Suntech Power was manifested as the first Chinese solar energy manufacturing firm going public at the New York Stock Exchange (NYSE) in December 2005 (Liu, 2015). Inspired by the Suntech initial success, Wuxi government 
initiated the Wuxi "530 Plan" in April 2006, which aimed within 5 years to attract 30 advanced Chinese overseas entrepreneurs to start ventures in the emerging high-tech industries, such as environment protection, renewable energy and biotechnology. "530 Plan" coined with a "three times one hundred" policy, which specifies that start-up firms may receive 1 million start-up capital (100 Wan Chinese RMB), 100 square meters office space and 100 square meters accommodation free of charge for the initial three years (Liu, 2011). Returnee entrepreneurs and their teams need to apply for "530 Plan" in order to receive the aforementioned policy support. Returnee entrepreneurs as knowledge carrier bring advanced technology, new product knowledge, and know-how beyond geographical boundaries. Wuxi accumulated a large multitude of returnees, both as individuals and groups collectively, constituted the knowledge base for potential knowledge exchange.

As an official organization of returnees, WXOCICC (Wuxi Overseas Chinese Investment Chamber of Commerce) plays an important role in Wuxi in promoting regional entrepreneurship and innovation. Given the absence of high caliber university (neither old university capacity was adequate, nor new university was established), there is the need to fill the void of university capacity. Hereby, WXOCICC played the role as regional hub to channel information between government, returnees and business sector. For instance, returnee association attempted to engage proactively in the provision of entrepreneurship training for aspiring entrepreneurs.

The current chairman of WXOCICC, a returnee himself, explained:

"Our association actually provides entrepreneurial trainings and workshops to aspiring returnee entrepreneurs. For instance, we invite local professional firms on a regular basis to give seminars to young nascent returnee entrepreneurs. Topics include Chinese corporate law, and taxation etc."

Interestingly, returnee association took the lead in regional entrepreneurship and innovation by mobilizing resources and cultivating a supportive atmosphere towards entrepreneurship.

Furthermore, the returnee association facilitated potential collaboration between their members (returnees) and local businesses. Knowledge exchange between returnees and local industry sector possesses synergistic potential. Jack told,

"The knowledge transfer between returnees and local business can generate huge potential benefits. The returnees have the technology whereas the local firms understand the Chinese markets well. By working together, both returnees and local business can benefit and learn from each other. For instance a joint venture was formed by a returnee and a local business to enable 'technology meets market'.",

In a nutshell, our analysis revealed empirically two different approaches in addressing university capability in the two cities, either nurturing university capability by establishing new universities and institutions, or attracting returnee entrepreneurial talent to compensate university capability. Both approaches could help achieve certain university capability 
discussed earlier, which in turn contribute to innovation and regional development to different extent.

\section{Discussion and Conclusion}

Extant research has largely applied the Tripe Helix model to analyze innovation and regional development on national and regional levels, whereas university is assumed to play a primary role. However, it begs the question what university capability is and how regions lacking such capability can prosper. Based on the micro-foundational thinking, our study attempts to articulate and conceptualize university capability by illuminating the differences between resources and capabilities. Furthermore, we map out university capability with key functions of university, namely knowledge base, knowledge exchange and regional outcomes. In so doing, the functions of university in Triple Helix are made explicit, so as to offer the common ground to explore university capability as one important micro-foundation of the Triple Helix model.

\subsection{Theoretical contribution}

Our study may significantly extend the understanding of Triple Helix model by explicating the role of university and prevalent assumptions, and more importantly unpacking university capability. By building up the literature stream on organizational capability, we distinguished resources and capabilities while conceptualizing the construct of university capability. In so doing, we connect with and contribute to the literature streams on resources and capabilities in the context of entrepreneurial university. In addition, we explored university capability from an audience evaluative perspective. In the context of Triple Helix, university capability may be defined as 'the ability of a university to allocate and co-ordinate resources for the mission of regional engagement and development'. The key characteristics include mission statement which manifestoes the university's commitment to regional engagement and contribution, accordingly a mechanism in place to facilitate resource allocation and coordination towards desired outcomes. Our novel conceptualization of university capability consists of four key elements that connect resources and capabilities by articulating (1) resource base, (2) motivation/objective, (3) resource allocation and co-ordination mechanisms, and (4) regional outcomes. In so doing, our study offers a nuanced understanding of the notion of university capability. Importantly, our approach in assessing university capability from an external audience perspective extends the current internaloriented view on university capability (Rasmussen \& Borch, 2010).

Furthermore, our study may contribute to the Triple Helix literature by suggesting university capability as one micro-foundation for Triple Helix model. Recent research has begun to emphasize the importance of micro-foundation in organization and management theory (Barney \& Felin, 2013). Our study extends this line of reasoning by offering empirical evidence and a contextualized understanding of university capability in the Triple Helix model. By examining university capability in the context of the regional innovation and 
entrepreneurship, we extend prior work on Triple Helix model and suggest university capability as one important micro-foundation for Triple Helix model within which future researchers may further extend the body of knowledge on this conceptualization.

This study also enhances our understanding on how the role of university in the Triple Helix model could be addressed or compensated, if university capability is missing. Our findings show two possible pathways that may address the lack of university capability in regional innovation and development, namely cultivating university capability or collective entrepreneurial activities to substitute university capability. Importantly, our findings demonstrate the plausible variations of government policy and its implications on Triple Helix in emerging economies and university capability in particular.

\subsection{Managerial and policy implications}

This study offers several implications to policymakers, higher educational institutions, and entrepreneurs. The unprecedented pace of economic development in emerging economies confronts policymakers and business leaders in a globalized and interconnected business environment. Government should recognize and pay close attention to university capability and their role in regional innovation and development. A nuanced understanding of university capability may facilitate the involved actors to respond accordingly. The various regional contexts and situations engender multiple opportunities to a wide spectrum of stakeholders. When the region in emerging economies chooses to build up university capacity, overseas higher institutions may actively contribute to shape this process and profit from such a capacity-building endeavor by proactive participation and bringing in knowledge and knowhow. Nevertheless, university needs to cultivate 'capability', such as statement as signal for collaboration, and the appropriate mechanisms to facilitate the allocation and coordination of resources. Furthermore, the entrepreneurial university (Foss \& Gibson, 2015) can take initiatives together with government and industry to create a support structure for firm formation and regional growth, which in turn may lead to a self-sustaining dynamic (Etzkowitz, 2008; Etzkowitz \& Klofsten, 2005). In so doing, the desired regional outcomes may be achieved.

Our research indicates that government tried to attract overseas talents to return their home country may compensate to certain extent the lack of university capability in promoting regional innovation and entrepreneurship agenda. Against the backdrop of globalization and the continuously increasing interconnectedness of the world business beyond geographical boundaries, entrepreneurs can launch global ventures at the outset in the pursuit of entrepreneurial spirit (Glaister, Liu, Sahadev, \& Gomes, 2014; Isenberg, 2008). Collective entrepreneurial activities may unleash the potential of returnees to substitute the key functions of university. This study can shed some light on policy making and implementation to refine regional innovation and entrepreneurship policy and to cultivate the atmosphere that is conducive to attracting global talent and returnees. 
Our findings largely confirm the importance of university capability in regional development and innovation. By unpacking the different key elements of university capability that constitutes one important micro-foundation of Triple Helix model, our paper illuminates the approaches in addressing university capability, i.e., building or substituting, according to the audience's assessment. Both approaches seem to have achieved university capability to certain extent. However, due to relatively short history of university, nurturing approach encounters complex issues and challenges to capture fully its potential value, whereas substituting approach reconciles the returnees' entrepreneurial endeavors that might be challenged by the local situation. Furthermore, talent mobility leads the substituting approach vulnerable and potentially less sustainable from a long term perspective.

\subsection{Limitations and future research}

This paper offers a conceptualization of university capability in the Triple Helix model. Furthermore, we offer empirical evidence on how university capability can be addressed by unpacking the four key elements of university capability. Although our conceptualization is

supported by case studies of two adjacent regions in China, we view our findings as tentative and suggest future research efforts validate our conceptualization by using quantitative approach to capture the university capability. In addition, future research can also compare university capability in emerging economies with their counterpart in advanced economies, so as to attain an enhanced understanding of comparative regional innovation and entrepreneurship (Mian, 2011).

Another fruitful research stream relates to the recent conversation on micro-foundations. Our research shows the applicability and potential value of micro-foundational thinking to advance Triple Helix research. Future research can explore other potential micro-foundations of the Triple Helix model from a multi-level perspective, such as Principle Investigators as micro-foundation (O'kane, Cunningham, Mangematin, \& O'Reilly, 2013). Hence, we suggest further research might build upon our conceptualization of university capability as microfoundation to add additional micro-foundations, so as to gain a more comprehensive understanding of micro-foundations and its influence on the Triple Helix model in particular and regional innovation and entrepreneurship in general.

\subsection{Conclusion}

Our study underpins the idea that understanding the role of university, its capability, and its relationship with other two actors in a nuanced manner from a micro-foundational perspective is important to advance the Triple Helix model. In particular, our conceptualization of university capability is an attempt to elucidate the complexity and interaction of university-industry-government and serves as a departure point for further theoretical refinement and empirical validation. Our paper offers regional entrepreneurial and innovation policy implications that might shed some light to regions where university 
capability is lacking. In a nutshell, the regional innovation and entrepreneurial development can still be realized through other mechanisms to compensate the lack of university capability. We hope this study inspires scholars to further investigate this line of inquiry on the role of university and university capability in regional innovation and entrepreneurship. 


\section{References}

Amit, R., \& Schoemaker, P. J. 1993. Strategic assets and organizational rent. Strategic Management Journal, 14(1): 33-46.

Anderson, T. R., Daim, T. U., \& Lavoie, F. F. 2007. Measuring the efficiency of university technology transfer. Technovation, 27(5): 306-318.

Balconi, M., \& Laboranti, A. 2006. University-industry interactions in applied research: The case of microelectronics. Research Policy, 35(10): 1616-1630.

Barney, J., \& Felin, T. 2013. What Are Microfoundations? Academy of Management Perspectives, 27(2): 138-155.

Bartelse, J., \& van Vught, F. 2009. The European higher education classification: Objectives and concepts. In F. van Vught (Ed.), Mapping the Higher Education Landscape: Towards a European Classification of Higher Education: 57-69. Netherlands: Springer.

Bathelt, H., Malmberg, A., \& Maskell, P. 2004. Clusters and knowledge: local buzz, global pipelines and the process of knowledge creation. Progress in human geography, 28(1): 31-56.

Carayannis, E. G., Alexander, J., \& Ioannidis, A. 2000. Leveraging knowledge, learning, and innovation in forming strategic government-university-industry (GUI) R\&D partnerships in the US, Germany, and France. Technovation, 20(9): 477-488.

Coviello, N. E., \& Jones, M. V. 2004. Methodological issues in international entrepreneurship research. Journal of Business Venturing, 19(4): 485-508.

Devinney, T. 2013. Is Microfoundational Thinking Critical to Management Thought and Practice? The Academy of Management Perspectives, 27(2): 81-84.

Eisenhardt, K. M. 1989. Building theories from case study research. Academy of management review: $532-550$.

Eisenhardt, K. M., \& Graebner, M. E. 2007. Theory building from cases: Opportunities and challenges. The Academy of Management Journal Archive, 50(1): 25-32.

Etzkowitz, H. 2003. Research groups as 'quasi-firms': the invention of the entrepreneurial university. Research policy, 32(1): 109-121.

Etzkowitz, H. 2008. The Triple Helix: University-Industry-Government Innovation in Action London: Routledge.

Etzkowitz, H. 2012. Triple helix clusters: boundary permeability at university-industry-government interfaces as a regional innovation strategy. Environment and Planning-Part C, 30(5): 766.

Etzkowitz, H., \& Klofsten, M. 2005. The innovating region: toward a theory of knowledge-based regional development. $\boldsymbol{R} \& \boldsymbol{D}$ Management, 35(3): 243-255.

Etzkowitz, H., Webster, A., Gebhardt, C., \& Terra, B. R. C. 2000. The future of the university and the university of the future: evolution of ivory tower to entrepreneurial paradigm. Research Policy, 29(2): 313-330.

Felin, T., Foss, N. J., \& Ployhart, R. E. 2015. The microfoundations movement in strategy and organization theory. The Academy of Management Annals, 9(1): 575-632.

Foss, L., \& Gibson, D. v. 2015. The Entrepreneurial University: Context and Institutional Change. New York: Routledge.

Fugazzotto, S. J. 2009. Mission statements, physical space, and strategy in higher education. Innovative Higher Education, 34(5): 285-298.

Glaister, A. J., Liu, Y., Sahadev, S., \& Gomes, E. 2014. Externalizing, internalizing and fostering commitment: The case of born-global firms in emerging economies. Management International Review, 54(4): 473-496.

Grant, R. M. 1996. Prospering in dynamically-competitive environments: Organizational capability as knowledge integration. Organization Science, 7(4): 375-387.

Helfat, C. E., \& Peteraf, M. A. 2003. The dynamic resource-based view: capability lifecycles. Strategic Management Journal, 24(10): 997-1010.

Isenberg, D. J. 2008. The global entrepreneur. Harvard Business Review, 86(12): 107-111.

Jacob, M., Lundqvist, M., \& Hellsmark, H. 2003. Entrepreneurial transformations in the Swedish University system: the case of Chalmers University of Technology. Research Policy, 32(9): 1555-1568. 
Krippendorff, K. 2012. Content analysis: An introduction to its methodology. Thousand Oaks, CA: SAGE Publications.

Lawton Smith, H., \& Bagchi-Sen, S. 2010. Triple helix and regional development: a perspective from Oxfordshire in the UK. Technology Analysis \& Strategic Management, 22(7): 805-818.

Lawton Smith, H., \& Bagchi-Sen, S. 2012. The research university, entrepreneurship and regional development: Research propositions and current evidence. Entrepreneurship \& Regional Development, 24(5-6): 383-404.

Leitch, C., Hill, F., \& Neergaard, H. 2010. Entrepreneurial and business growth and the quest for a "comprehensive theory": tilting at windmills? Entrepreneurship Theory and Practice, 34(2): 249-260.

Leydesdorff, L., \& Etzkowitz, H. 1998. The triple helix as a model for innovation studies. Science and public policy, 25(3): 195-203.

Liu, Y. 2011. High-tech ventures' innovation and influences of institutional voids: A comparative study of two high-tech parks in China. Journal of Chinese Entrepreneurship, 3(2): 112-133.

Liu, Y. 2015. Born global firms' growth and collaborative entry mode: The role of transnational entrepreneurs. International Marketing Review, Forthcoming.

Liu, Y., \& Almor, T. 2014. How culture influences the way entrepreneurs deal with uncertainty in inter-organizational relationships: The case of returnee versus local entrepreneurs in China. International Business Review, DOI: 10.1016/j.ibusrev.2014.11.002.

Liu, Y., Cao, X., \& Xing, Y. 2013. A Tale of Two Cities in Regional Entrepreneurial Policymaking: A Comparative Study of Suzhou and Wuxi from a Path Dependence Perspective. In J. Sydow, \& G. Schreyoegg (Eds.), Self-reinforcing Processes in and among Organizations: 55-78. London: Palgrave Macmillan.

Lockett, A., \& Wright, M. 2005. Resources, capabilities, risk capital and the creation of university spin-out companies. Research policy, 34(7): 1043-1057.

Mangematin, V., O'Reilly, P., \& Cunningham, J. 2014. PIs as boundary spanners, science and market shapers. The Journal of Technology Transfer, 39(1): 1-10.

Marques, J., Caraça, J. M., \& Diz, H. 2006. How can university-industry-government interactions change the innovation scenario in Portugal? - the case of the University of Coimbra. Technovation, 26(4): 534-542.

Mian, S. A. 2011. Science and Technology Based Regional Entrepreneurship: Global Experience in Policy and Program Development. Cheltenham, UK: Edward Elgar Publishing.

Miles, M. B., \& Huberman, A. M. 1994. Qualitative data analysis: An expanded sourcebook. London: Sage.

Morphew, C. C., \& Hartley, M. 2006. Mission statements: A thematic analysis of rhetoric across institutional type. The Journal of Higher Education, 77(3): 456-471.

O'kane, C., Cunningham, J., Mangematin, V., \& O'Reilly, P. 2013. Underpinning Strategic Behaviours and Posture of Principal Investigators in Transition/Uncertain Environments. Long Range Planning, Available online 20 September 2013.

O'Kane, C., Mangematin, V., Geoghegan, W., \& Fitzgerald, C. 2015. University technology transfer offices: The search for identity to build legitimacy. Research Policy, 44(2): 421-437.

Rasmussen, E., \& Borch, O. J. 2010. University capabilities in facilitating entrepreneurship: A longitudinal study of spin-off ventures at mid-range universities. Research Policy, 39(5): 602612.

Stokes, P., Liu, Y., Smith, S., Leidner, S., Moore, N., \& Rowland, C. 2015. Managing talent across advanced and emerging economies: HR issues and challenges in a Sino-German strategic collaboration. The International Journal of Human Resource Management, DOI: 10.1080/09585192.2015.1074090.

Teece, D. J. 2014. The foundations of enterprise performance: Dynamic and ordinary capabilities in an (economic) theory of firms. The Academy of Management Perspectives, 28(4): 328-352.

Teece, D. J., Pisano, G., \& Shuen, A. 1997. Dynamic capabilities and strategic management. Strategic Management Journal, 18(7): 509-533.

Vaara, E., \& Monin, P. 2010. A Recursive Perspective on Discursive Legitimation and Organizational Action in Mergers and Acquisitions. Organization Science, 21(1): 3-22. 
Wang, H., \& Liu, Y. 2015. Entrepreneurship and Talent Management from a Global Perspective: Global Returnees. Cheltenham: Edward Elgar.

Wei, Y. D., Lu, Y., \& Chen, W. 2009. Globalizing regional development in Sunan, China: does Suzhou Industrial Park fit a neo-Marshallian district model? Regional Studies, 43(3): 409427.

Wright, M., Liu, X., Buck, T., \& Filatotchev, I. 2008. Returnee Entrepreneurs, Science Park Location Choice and Performance: An Analysis of High-Technology SMEs in China. Entrepreneurship Theory and Practice, 32(1): 131-155.

Yeoh, C., Pow Ngee How, W., \& Lin Leong, A. 2005. 'Created'enclaves for enterprise: an empirical study of Singapore's industrial parks in Indonesia, Vietnam and China. Entrepreneurship \& Regional Development, 17(6): 479-499.

Yin, R. K. 2009. Case study research: Design and methods: Sage publications, INC.

Youtie, J., \& Shapira, P. 2008. Building an innovation hub: A case study of the transformation of university roles in regional technological and economic development. Research Policy, 37(8): 1188-1204.

Zahra, S. A., Wright, M., \& Abdelgawad, S. G. 2014. Contextualization and the advancement of entrepreneurship research. International Small Business Journal, 32(5): 479-500. 
Table 1: An overview of interview informants

\begin{tabular}{lc}
\hline Informants & Number of interviews \\
\hline Government officials & 10 \\
High-tech park & $(5)$ \\
Regional gov. officials & $(5)$ \\
Higher education institutions & 6 \\
Management team & $(3)$ \\
Faculty staff & $(3)$ \\
Industry $\quad 13$ \\
Returnees
\end{tabular}


Table 2: A summary of policy documents analyzed

\begin{tabular}{|c|c|c|c|c|}
\hline Timeline & $\begin{array}{l}\text { Key policy documents in } \\
\text { Suzhou }\end{array}$ & Policy issues in Suzhou & $\begin{array}{l}\text { Key policy documents } \\
\text { in Wuxi }\end{array}$ & Policy issues in Wuxi \\
\hline 2006 & $\begin{array}{l}\text { "The 11th Five-Year Plan of } \\
\text { Professionals Development in } \\
\text { SIP" }\end{array}$ & $\begin{array}{l}\text { To create more sustained } \\
\text { mechanisms to attract } \\
\text { professionals and talents } \\
\text { working, living, studying in } \\
\text { Suzhou }\end{array}$ & $\begin{array}{l}\text { "Decision on } \\
\text { implementing } 530 \text { Plan" }\end{array}$ & $\begin{array}{l}\text { To attract overseas expatriates to } \\
\text { start-up businesses with their special } \\
\text { technology know-how }\end{array}$ \\
\hline 2008 & $\begin{array}{l}\text { "Industry Planning to Develop } \\
\text { Service-Outsourcing Industry in } \\
\text { SIP" }\end{array}$ & $\begin{array}{l}\text { To develop service-outsourcing } \\
\text { industry, including ITO, BPO, } \\
\text { KPO, CRO. In 2007.4, SIP has } \\
\text { been approved by Ministry of } \\
\text { Commerce to be one of the } 12 \\
\text { 'Demonstration Zone' of } \\
\text { service-outsourcing industry. }\end{array}$ & $\begin{array}{l}\text { "Plans of Propelling } \\
\text { Commercialization of } \\
\text { Pioneering Returnee } \\
\text { Entrepreneurs' Projects" }\end{array}$ & $\begin{array}{l}\text { To implement industrialization and } \\
\text { commercialization of technologies } \\
\text { from overseas expatriates }\end{array}$ \\
\hline 2008.11 & $\begin{array}{l}\text { "Decision to revise 'SIPs } \\
\text { Policies' to attract and introduce } \\
\text { high level talents and } \\
\text { professionals in short supply" }\end{array}$ & $\begin{array}{l}\text { To modify and update SIP } \\
\text { policies to attract high-level } \\
\text { talents to Suzhou. }\end{array}$ & $\begin{array}{l}\text { "Approval of } \\
\text { Development Planning of } \\
\text { Wuxi as National High- } \\
\text { Tech Industries Base" }\end{array}$ & $\begin{array}{l}\text { Aim to get another reputation as a } \\
\text { national 'Base' }\end{array}$ \\
\hline 2009 & $\begin{array}{l}\text { "Decisions to deepen the role of } \\
\text { professionals in transferring and } \\
\text { upgrading" }\end{array}$ & $\begin{array}{l}\text { To establish comprehensive } \\
\text { environment to attract high-level } \\
\text { talents, to strengthen link } \\
\text { between industry and education, }\end{array}$ & $\begin{array}{l}\text { "Decision on setting up } \\
\text { ‘530 Plan' Experts } \\
\text { Consulting Committee" }\end{array}$ & $\begin{array}{l}\text { To set up consulting committee to } \\
\text { facilitate '530 Plan' investment } \\
\text { decisions }\end{array}$ \\
\hline 2010 & $\begin{array}{l}\text { "Creation of National } \\
\text { Entrepreneurship Mother Fund" }\end{array}$ & $\begin{array}{l}\text { To set up RMB investment fund } \\
\text { for optional investment }\end{array}$ & $\begin{array}{l}\text { "Notice for } 530 \text { Plan and } \\
\text { Pan-530 Plan" }\end{array}$ & $\begin{array}{l}\text { To set up a sister 'Pan-530 Plan' to } \\
\text { attract } 30 \text { foreign technology } \\
\text { leading experts over two years }\end{array}$ \\
\hline 2011 & $\begin{array}{l}\text { "Establishment of National } \\
\text { 'Thousand Talents' } \\
\text { Entrepreneurship Investment } \\
\text { Center" }\end{array}$ & $\begin{array}{l}\text { To provide finance solution for } \\
\text { returnee high-level expatriates, } \\
\text { cultivating new industry } \\
\text { development }\end{array}$ & $\begin{array}{l}\text { "Exhibition of } 530 \text { Plan } \\
\text { program achievements" }\end{array}$ & $\begin{array}{l}\text { To celebrate the achievement of } 530 \\
\text { Plan with continuous plan to build } \\
\text { Eastern Silicon Valley }\end{array}$ \\
\hline
\end{tabular}


Table 3: Comparison of university capability from an audience's perspective

\begin{tabular}{|c|c|c|c|c|c|}
\hline \multirow{2}{*}{$\begin{array}{l}\text { Elements of } \\
\text { university } \\
\text { capability }\end{array}$} & \multirow{2}{*}{$\begin{array}{l}\text { Dimensions of } \\
\text { university } \\
\text { function }^{1}\end{array}$} & \multicolumn{2}{|c|}{ Jiangnan University, Wuxi } & \multicolumn{2}{|c|}{ Xi'an Jiaotong Liverpool University, Suzhou } \\
\hline & & View of government & View from industry & View of government & View of industry \\
\hline \multirow[t]{2}{*}{$\begin{array}{l}\text { Mission/ } \\
\text { objectives }\end{array}$} & $\begin{array}{l}\text { Knowledge } \\
\text { base }\end{array}$ & $\begin{array}{l}\text { Specialized regional } \\
\text { university }\end{array}$ & $\begin{array}{l}\text { Specialized industry } \\
\text { expertise, such as textile, } \\
\text { but less adapted to } \\
\text { emerging high-tech } \\
\text { industry, such as } \\
\text { renewable energy }\end{array}$ & $\begin{array}{l}\text { Entrepreneurial university. } \\
\text { To become a leading } \\
\text { research-led university with } \\
\text { a strong international } \\
\text { profile }\end{array}$ & $\begin{array}{l}\text { Strong motivation to } \\
\text { collaborate with industry, esp. } \\
\text { foreign invested firms in } \\
\text { Suzhou Industrial Park }\end{array}$ \\
\hline & & $\begin{array}{l}\text { Lack of preparation to suit } \\
\text { high-tech industry } \\
\text { demand for regional } \\
\text { development }\end{array}$ & $\begin{array}{l}\text { Lack of high quality } \\
\text { workforce from } \\
\text { university, need returnees } \\
\text { to compensate }\end{array}$ & $\begin{array}{l}\text { Strong commitment to use } \\
\text { knowledge to promote } \\
\text { regional economic } \\
\text { development }\end{array}$ & $\begin{array}{l}\text { High quality workforce from } \\
\text { university for local business }\end{array}$ \\
\hline \multirow[t]{2}{*}{ Resource } & $\begin{array}{l}\text { Knowledge } \\
\text { base }\end{array}$ & $\begin{array}{l}\text { Non- } 985 \text { project } \\
\text { university }\end{array}$ & $\begin{array}{l}\text { Specialized majors } \\
\text { with relatively less } \\
\text { resource endorsement }\end{array}$ & $\begin{array}{l}\text { Support from Xi'an Jiao } \\
\text { Tong University ( } 985 \\
\text { project university) and } \\
\text { Liverpool University } \\
\left(\text { Russell Group }{ }^{2}\right)\end{array}$ & $\begin{array}{l}\text { Industry funding project and } \\
\text { consulting projects }\end{array}$ \\
\hline & & $\begin{array}{l}\text { Focus on tailored teaching } \\
\text { program with specialized } \\
\text { majors (e.g. textile } \\
\text { industry) }\end{array}$ & $\begin{array}{l}\text { Returnees assist local } \\
\text { university by leveraging } \\
\text { knowledge and know-how }\end{array}$ & $\begin{array}{l}\text { Quality education with high } \\
\text { calibre faculty and teaching } \\
\text { program }\end{array}$ & $\begin{array}{l}\text { Leading laboratory to work } \\
\text { with industry }\end{array}$ \\
\hline
\end{tabular}




\section{Co-ordination Knowledge}

mechanisms

exchange

Regional
outcomes
Collaboration within previous independent colleges

Lack of knowledge transfer between university and industry

Consolidation and merger of old universities and higher education institutions
Less supply of talent to local, particularly in the high-tech disciplines

Returnees as knowledge carrier to share and spill over knowledge to local business people
Part of Suzhou Dushu Lake Higher Education Town

Sharing facilities among universities including libraries, entertainment venues, a sports centre and accommodation

Less capable to reflect the high-tech demand, such as renewable industry, biotechnology

Limited to constraints of

To enlarge "size" and achieve efficiency for university operation
Planned project within the Suzhou Dushu Lake Higher Education Town

Respond to MNEs demand for industry upgrading specialized majors (e.g.

Textile Science, Light

Industry Technology)
Potential acquisition target for innovation and commercialization from university projects

Knowledge transfer between university and industry
Comprehensive university with coverage of Science, Technology, Engineering, Architecture and Business

Establishment of International Business School Suzhou in 2012 embraces the spirit of enterprise

\section{Notes:}

1. Dimensions of university function adapted from U-Map (Bartelse \& van Vught, 2009).

2. The Russell Group represents 24 leading UK universities which are committed to maintaining the very best research, an outstanding teaching and learning experience and unrivalled links with business and the public sector. (http://www.russellgroup.ac.uk/) 
Table 4. A comparative analysis of two approaches in addressing university capability

\begin{tabular}{|c|c|c|c|c|c|c|}
\hline $\begin{array}{l}\text { University } \\
\text { function }\end{array}$ & $\begin{array}{l}\text { University } \\
\text { function } \\
\text { indicator }\end{array}$ & $\begin{array}{l}\text { Nurturing } \\
\text { approach } \\
\text { mechanisms }\end{array}$ & Selective empirical evidence & $\begin{array}{l}\text { University } \\
\text { function } \\
\text { indicator }\end{array}$ & $\begin{array}{l}\text { Substituting } \\
\text { approach } \\
\text { mechanisms }\end{array}$ & Selective empirical evidence \\
\hline \multirow[t]{2}{*}{$\begin{array}{l}\text { Knowledge } \\
\text { base }\end{array}$} & $\begin{array}{l}\text { Teaching and } \\
\text { learning }\end{array}$ & $\begin{array}{l}\text { Recruiting } \\
\text { faculty and } \\
\text { students to } \\
\text { university }\end{array}$ & $\begin{array}{l}\text { "We actively recruit the top faculty } \\
\text { internationally, from North } \\
\text { America or Europe, and offer the } \\
\text { excellent learning opportunities for } \\
\text { our student" }\end{array}$ & $\begin{array}{l}\text { Teaching and } \\
\text { learning }\end{array}$ & $\begin{array}{l}\text { Bringing across } \\
\text { geographical } \\
\text { boundaries by } \\
\text { returnees }\end{array}$ & $\begin{array}{l}\text { "As for core founding team, we } \\
\text { came back from Silicon Valley, but } \\
\text { I need to recruit local labor force to } \\
\text { work for us. We need to teach our } \\
\text { locally recruited employees the } \\
\text { skills and knowledge on the job." }\end{array}$ \\
\hline & Start-up firms & $\begin{array}{l}\text { Academic } \\
\text { entrepreneurs }\end{array}$ & $\begin{array}{l}\text { "I found my venture because I saw } \\
\text { the opportunity while working with } \\
\text { industry partner. I imagine it would } \\
\text { not be easy to do so without this } \\
\text { Suzhou campus where industry } \\
\text { base is strong." }\end{array}$ & Start-up firms & Returnee ventures & $\begin{array}{l}\text { "As a returnee, the prerequisite to } \\
\text { receive government support with } \\
\text { the } 530 \text { plan is I need to found my } \\
\text { own technology venture in Wuxi." }\end{array}$ \\
\hline \multirow[t]{2}{*}{$\begin{array}{l}\text { Knowledge } \\
\text { exchange }\end{array}$} & $\begin{array}{l}\text { Knowledge } \\
\text { transfer }\end{array}$ & $\begin{array}{l}\text { Sending } \\
\text { students to } \\
\text { industry for } \\
\text { internship }\end{array}$ & $\begin{array}{l}\text { "We work with industry partners } \\
\text { and send our students to do } \\
\text { internships with them. For industry } \\
\text { partners, the cost is relatively low. } \\
\text { Both students and industry partners } \\
\text { can learn something through close } \\
\text { interaction, including us as faculty } \\
\text { member." }\end{array}$ & $\begin{array}{l}\text { Knowledge } \\
\text { transfer }\end{array}$ & $\begin{array}{l}\text { Collective } \\
\text { entrepreneurial } \\
\text { behaviors }\end{array}$ & $\begin{array}{l}\text { "The pioneer entrepreneurs have to } \\
\text { pass on the knowledge about local } \\
\text { business environment and Chinese } \\
\text { business practices to the late- } \\
\text { comers returnee entrepreneurs. } \\
\text { Returnee left the country for a long } \\
\text { time, so they need to get re-learn } \\
\text { the local practices" }\end{array}$ \\
\hline & & $\begin{array}{l}\text { University and } \\
\text { industry } \\
\text { collaborative } \\
\text { projects }\end{array}$ & $\begin{array}{l}\text { "Our university contributes } \\
\text { significantly to this region although } \\
\text { we were newly established. We } \\
\text { carried joint project with firms in }\end{array}$ & & $\begin{array}{l}\text { Returnees work } \\
\text { with local } \\
\text { business }\end{array}$ & $\begin{array}{l}\text { "The knowledge transfer between } \\
\text { returnees and local business can } \\
\text { generate huge potential benefits, } \\
\text { because the returnees have the } \\
\text { technology whereas the local }\end{array}$ \\
\hline
\end{tabular}




\begin{tabular}{|c|c|c|c|c|c|c|}
\hline \multirow{4}{*}{$\begin{array}{l}\text { Regional } \\
\text { outcomes }\end{array}$} & & & $\begin{array}{l}\text { SIP. It is much easier to do than } \\
\text { before, because the firms seek for } \\
\text { partners who are capable to } \\
\text { undertake collaboration for R\&D } \\
\text { project." }\end{array}$ & & & $\begin{array}{l}\text { business firms understand the } \\
\text { Chinese markets well. By working } \\
\text { together, both returnees and local } \\
\text { business firms can benefit and learn } \\
\text { from each other" }\end{array}$ \\
\hline & $\begin{array}{l}\text { Engagement, } \\
\text { provision of } \\
\text { entrepreneursh } \\
\text { ip training }\end{array}$ & University & $\begin{array}{l}\text { "We offer enterprise training course } \\
\text { for aspiring entrepreneurs. Also, } \\
\text { part-time program to employee } \\
\text { from local business." }\end{array}$ & $\begin{array}{l}\text { Engagement, } \\
\text { provision of } \\
\text { entrepreneurship } \\
\text { training }\end{array}$ & $\begin{array}{l}\text { Returnees } \\
\text { association }\end{array}$ & $\begin{array}{l}\text { "Our association actually provides } \\
\text { the entrepreneurial trainings and } \\
\text { workshops to aspiring returnee } \\
\text { entrepreneurs. For instance, we } \\
\text { invite local professional firms on a } \\
\text { regular basis to give seminars to } \\
\text { young nascent returnee } \\
\text { entrepreneurs. Topics include } \\
\text { Chinese corporate law, taxation." }\end{array}$ \\
\hline & $\begin{array}{l}\text { Provision of } \\
\text { talent }\end{array}$ & $\begin{array}{l}\text { Supplying } \\
\text { qualified labor } \\
\text { force }\end{array}$ & $\begin{array}{l}\text { "If we could have good quality } \\
\text { university in Suzhou, the university } \\
\text { might attract top students to come } \\
\text { to our city. Furthermore, the } \\
\text { university graduates might stay to } \\
\text { contribute to local economy." }\end{array}$ & $\begin{array}{l}\text { Provision of } \\
\text { talent }\end{array}$ & Talent mobility & $\begin{array}{l}\text { "The arrival of talents brings an } \\
\text { upgrade for the citizen composition. } \\
\text { In the past, Wuxi lacked culture. } \\
\text { Now we attract many highly- } \\
\text { educated entrepreneurs, many of } \\
\text { them have PhD degrees from } \\
\text { abroad." }\end{array}$ \\
\hline & $\begin{array}{l}\text { Regional } \\
\text { support } \\
\text { structure }\end{array}$ & University-led & $\begin{array}{l}\text { "Newly established universities can } \\
\text { act as the hub to connect different } \\
\text { partners from industry and business } \\
\text { sectors. Also, government support } \\
\text { plays a very important role to } \\
\text { enable this university-industry } \\
\text { collaboration, such as funding the } \\
\text { programs offered by universities or } \\
\text { research funding schemes that } \\
\text { involve both university and } \\
\text { industry" }\end{array}$ & $\begin{array}{l}\text { Regional } \\
\text { support structure }\end{array}$ & $\begin{array}{l}\text { Returnee } \\
\text { association -led }\end{array}$ & $\begin{array}{l}\text { "Our Chamber has four missions: } \\
\text { Information platform, entrepreneur } \\
\text { helper, channel between } \\
\text { entrepreneurs and government, and } \\
\text { the elite circle of overseas } \\
\text { entrepreneurs. We offer various } \\
\text { services surrounding our missions, } \\
\text { such as tailored training for returnee } \\
\text { entrepreneurs about Chinese } \\
\text { business environment, social } \\
\text { gathering for returnees to stimulate } \\
\text { business collaboration, etc." }\end{array}$ \\
\hline
\end{tabular}

